American Journal of Economics and Business Administration 3 (1): 47-57, 2011

ISSN 1945-5488

(C) 2010 Science Publications

\title{
Consumers' Perceived Quality, Perceived Value and Perceived Risk Towards Purchase Decision on Automobile
}

\author{
${ }^{1}$ Choy Johnn Yee, ${ }^{2} \mathrm{Ng}$ Cheng San \\ ${ }^{1}$ Department of Marketing \\ ${ }^{2}$ Department of Commerce and Accountancy \\ Faculty of Business and Finance, University Tunku Abdul Rahman, Perak Campus, \\ Jalan University, Bandar Barat, 31900 Kampar, Perak D.R., Malaysia \\ ${ }^{3}$ Ch'ng Huck Khoon \\ ${ }^{3}$ School of Business and Administration, Wawasan Open University, \\ 54, Jalan Sultan Ahmad Shah, 10050 Penang, Malaysia
}

\begin{abstract}
Problem statement: As the level of competition keep on increasing in Malaysia automobile market, it is essential for every automobile producer companies to understand customer insight in order to further increase their share of wallet. Thus, they need to understand what factors might influence their customers' decision in purchasing an automobile. Therefore, the objectives of this research is to study the relationships of perceived quality, perceived value and perceived risk that will affect on Malaysia consumer purchase decision towards cars. Approach: Survey using convenience sampling was done at Klang Valley to customers' age between 23-65 years old and above. Questionnaires were distributed to 200 respondents at the sampling location. Results: All the 200 sets of data were reliable where Cronbach's alpha is more than 0.6. Pearson correlation also showed the strength of the relationship between those variables and normality assumption was meet. Results from multiple regression analysis showed the positive association between the three factors mentioned previously with purchase decision. Conclusion/Recommendations: The results from this research provide a platform for Malaysia automobile makers to understand consumer behavior and how it affects their purchase decision. In order to ensure that the findings of sample are representative and conclusive, future research should be include with larger number of respondents.
\end{abstract}

Key words: Purchase decision, perceived value, perceived risk, consumers' perceived quality

\section{INTRODUCTION}

According to the announcement made by Ministry of International Trade and Industry in 23rd AFTA Council Meeting, in order to promote greater economic efficiency, productivity and competitiveness, Malaysia will be a complete free trade area effective from 1st January 2010, with the elimination of duties on over 2,000 tariff lines (Palaniappan, 2009). ASEAN Free Trade Area (AFTA) was formed in January 1992 at the 4th ASEAN Summit meeting in Singapore, when ASEAN (Association of Southeast Asian Nations) members (Indonesia, Malaysia, the Philippines, Singapore, Thailand and Brunei Darussalam) signed the Singapore Declaration and the Framework Agreement on Enhancing Economic Cooperation, with the objective to increase the ASEAN region's competitive advantage as a single production unit (Ministry of International Trade and Industry, 2009).

In 2008, Malaysia's total trade with ASEAN was RM297.59 billion (exports: RM171.19 billion; imports: RM126.40 billion). Under the Common Effective Preferential Tariff (CEPT) Preferential Scheme, Malaysia exports for 2008 amounted to RM16.06 billion, with RM10.61 billion for the past 6 months (Palaniappan, 2009). From AFTA policy, Malaysia has committed to eliminate import duties on 2123 products, which including 238 tariff lines in vehicles. Of the 'Big Three' markets, Malaysia with the first-half sales of 251,092 units outperformed Indonesia and Thailand to become the largest ASEAN vehicle market (Mark, 2009). This makes Malaysia become an attractive proposition and many foreign car makers intend to access into Malaysia market.

Corresponding Author: Choy Johnn Yee, Faculty of Business and Finance, University Tunku Abdul Rahman, Perak Campus, Jalan University, Bandar Barat, 31900 Kampar, Perak D.R., Malaysia 
Malaysia automobile industry started in the 1960sAND majority of the cars used on Malaysian roads were imported in the Cluster Box Unit (CBU) form. Malaysia has launched own national cars which is PROTON (Perusahaan Otomobil Nasional Berhad) in 1985. In 1994, Malaysia forms a joint venture with the Japanese automobile maker, Daihatsu and launched second national cars, PERODUA (Perusahaan Otomobil Kedua Sdn. Bhd.). In addition to national car, Malaysia has import the foreign cars, such as Toyota, Honda, Nissan, Mazda, Suzuki, Mitsubishi and Lexus from Japan; Hyundai and Kia from Korea; Ford and Chevrolet from United State; BMW, Mercedes, Ferrari, Peugeot, Fiat, Land Rover, Renault, Volkswagen, Volvo and Citroen from Europe.

Problem statement: The elimination of trade barriers among AFTA member states will open up market opportunities for ASEAN exporters to these neighboring countries. The results of decreasing car prices will increase the competitiveness of Malaysia automobile industry. For every single car maker in Malaysia, this becomes their challenge to compete effectively with those foreign car makers among ASEAN countries.

In order to remain competitiveness in Malaysia automobile industry, it is important for all car makers to know Malaysia consumers' behavior in purchasing automobile after the implementation of new AFTA policy. In short, they must understand whether decreasing in car prices will change Malaysia consumers' purchase behavior towards automobile (in other words, do Malaysia consumers behave the same way as before after implementation of new AFTA policy?) and if so, what factors Malaysia consumers use to make the purchase decision? Will they concern on perceived quality, perceived value and perceived risk when they want to purchase cars?

Research objectives: Primary objective of this research is to study the relationships of 3 factors affecting purchase decision towards buying cars. More specifically:

- To examine the association between perceived quality and purchase decision

- To examine the association between perceived value and purchase decision

- To examine the association between perceived risk and purchase decision

\section{Research questions:}

- Does perceived quality have association with purchase decision towards Malaysia cars purchaser?
- Does perceived value have association with purchase decision towards Malaysia cars purchaser?

- Does perceived risk have association with purchase decision towards Malaysia cars purchaser?

Significance of the study: This research study is being conducted in order to provide a basis for the assessment of the future automobile industry in Malaysia after globalization, especially after the elimination on duties in AFTA policy, particularly on automobiles. Besides, it's helps to provide information on the marketing strategies to the Malaysian car makers in order to compete in Malaysia automobile industry. It also updates Malaysian car makers on the latest AFTA policy implement at Malaysia which will affect their business. Not only that, the result of the study is expected to be contributing to the understanding of the perceived quality, perceived value and perceived risk towards customers purchase decision that consist of 7 stages (Blackwell et al., 2006). However, in this study, only 5 stages of customers' decision process are adopted.

As a result, Malaysian car makers will be more aware and familiar on AFTA policy. Based on AFTA information, they can modify their strategies and making the right decision according to the elimination on duties in order to maintain their competitiveness in Malaysia automobiles industry. Other than that, Malaysian car makers also will have more understanding on consumer insight and making necessary adjustment to fulfill their customers' needs and wants. Furthermore, this research will be very useful for the car makers. They will know about the customers' perception when they want to purchase a car. So that, the car makers able to do better in their planning in order to compete with other competitors.

Literature review: In literature review, we are going to discuss the three independent variables (perceived quality, perceived value and perceived risk) and one dependent variable (purchase decision) from the past study done by other researchers. We will define and describe in details on each variable with the supporting literature done by others.

Purchase Decision (PD): According to Peter and Olson (2004), the key process in consumers' decision making is the integration process by which knowledge is combining to evaluate two or more alternative behavior and select one. Most of the large company research consumer buying decision in increasing detail to answer question about what consumer buy, where they buy, how and how much they buy, when they buy and why they buy (Kotler et al., 2005). There are seven 
stages of the consumer buying decision process which are need recognition, search for information, prepurchase evaluation alternatives, purchase, consumption, post-consumption evaluation and divestment (Blackwell et al., 2006). Purchase decision is the fourth stage in consumer buying decision process. According to the Consumer Decision Making Process Model (Blackwell et al., 2006), a purchase or intent to purchase is often influenced by other factors such as risk and involvement. For this study, the researcher has proposed three possible factors that may affect consumers' decision to purchase automobile. The three factors are perceived quality, perceived value and perceived risk.

Perceived Quality (PQ): Perceived quality is a critical element for consumer decision making; consequently, consumers will compare the quality of alternatives with regard to price within a category (Jin and Yong, 2005). According to Davis et al. (2003), perceived quality is directly related to the reputation of the firm that manufactures the product. However, National Quality Research Center or NQRC (1995) defined perceived quality as the degree to which a product or service provides key customer requirements (customization) and how reliably these requirements are delivered (reliability). Whereas Aaker (1991) and Zeithaml (1988a) said that perceived quality is not the actual quality of the brands or products, rather, it is the consumers' judgment about an entity's or a service's overall excellence or superiority.

Consumers often judge the quality of a product or service on the basis of a variety of informational cues that they associate with the product. Some of these cues are intrinsic to the products, whereas others are extrinsic. As defined by Zeithaml (1988b), cues that are intrinsic concern physical characteristics of the products itself, such as product's performance, features, reliability, conformance, durability, serviceability and aesthetics. On the other hand, extrinsic attributes are the cues that are external to the products itself, such as price, brand name, brand image, company reputation, manufacturer's image, retail store image and the country of origin. Perceived quality has direct impact on customer purchase decision and brand loyalty, especially during the time customers have less or no information of the products that they are going to purchase (Aaker, 1991; Armstrong and Kotler, 2003).

Perceived Value (PV): The term "value" used in this study refers to a judgment of preference by consumers (Gan et al., 2005). According to Cronin et al. (2000) and Zeithaml (1988b), perceived value is the customer's overall assessment of the utility of a product based on perceptions of what is received and what is given. Sweeney and Soutar (2001) and Woodruff (1997) define customer value as a customer-perceived preference for and evaluation of, product attributes, attribute performance and consequences in terms of the customer's goals and purposes. Stonewall (1992) defined value as function of product features, quality issues, delivery, service and price. He also added that "value is always determined by consumer, in his or her own terms, timing and testaments" and that "value is a perception, a view, or understanding made up of measurable components." Perceived value is a comprehensive form of customer evaluation of service. According to Rust and Oliver (1994), value can be conceptualized as the overall evaluation of the service consumption experience and can be encounter specific or a more enduring global evaluation. Value perception may also differ according to the usage situation (Anckar and D'Incau, 2002). Value is a "function of the overall quality and price of the firm's products and services compared to the competition" (Mokhtar et al., 2005).

Perceived Risk (PR): The concept of perceived risk was introduced by Tzeng et al. (2005), he proposes that risk be conceived in terms of the uncertainty and consequences associated with consumer actions, the result of which may or may not be pleasant. Perceived risk is defined as the uncertainty that consumers face when they cannot foresee the consequences of their purchased decision. This definition highlights two relevant dimension of perceived risk: uncertainty and consequences. When a consumer make a purchase decision, 'risk' implies 'great consequences of making a mistake' and 'degree of inconvenience of making a mistake' (Batra and Sinha, 2000; Bettman, 1979; Schiffman, 1972; Cox, 1967; Havlena and De Sarbo, 1991; Peter and Ryan, 1976). According to Zeithaml and Bitner (2003), perceived risk will typically influence early stage of consumer buying process. Beside that, Dowling and Staelin (1994) define risk as a consumer perception of uncertainty and adverse consequences of engaging in an activity. The notion of perceived risk as a key antecedent to consumer behavior has been establish in the past and may be factor influencing the purchased decision to buy a car. In others words, company will put more effort on measuring the inherent risk associated with the purchase decision-making process.

According to Mitchell (1992), perceived risk influences the five stages of the consumer decision making process, which will influence customer 
purchase decision towards car. Risk may manifest itself in a variety of way such as fear that a product may not possess desirable attributes, uncertainty regarding product performance or a sense that the purchase of a particular brand may invite social disapproval (Richardson et al., 1996). Although risk can be include many types (i.e., performance, financial, social, time and safety), Dunn et al. (1986) found that the first two type performance and financial risk were the most closely associated with the purchase decision.

According to Durovnik (2006), consumers are less interest on purchasing the product that is considers being risky endeavors. He also says that consumer will try to reduce the risk of using more time to survey and paying something. For instance, consumer would find out about the quality of a product from those who have firsthand experience. Country of origin also has an impact towards the perceived risk. Based on Ahmed et al. (2002), consumer infers attributes to the product based on country stereotype and experiences with a product from the country. Consumer may perceive less risk in purchasing product from the countries with a good image.

\section{MATERIALS AND METHODS}

Proposed framework of the research project is adapted from Jin and Yong (2005). We intend to examine the relationship of perceived quality, perceived value and perceived risk towards the purchase decision in high contact automobile industry.

The perceived quality, perceived value and perceived risk as independent variables while the purchase decision is the dependent variable in this model. The greater the perceived quality, perceived value and perceived risk will directly have significant positive effect towards the purchase decision. The relation of the independent variable and dependent variable are linked with three hypotheses respectively.

Hypotheses of the study: Recently, Richardson et al. (1996) cues usage in product evaluation, perceived quality, perceived risk and perceived value as factors influencing purchase decision. Then, studies showed that manufacturers as nowadays are successful in convincing consumers that absolute levels of real quality differ or that variation in quality presents consumers with risk. (Hoch and Banerji, 1993; Richardson et al., 1996). Therefore, this study intent to know whether consumers' perceived quality will affect their purchase decision towards automobile (Fig. 1). Thus, the first hypothesis would be:

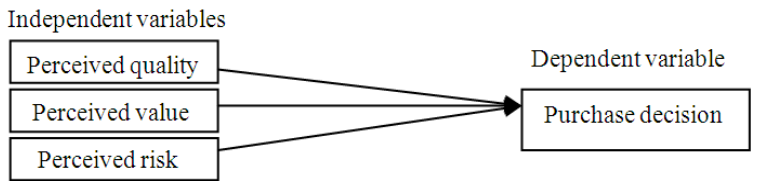

Fig. 1: A study on Malaysia consumer perception towards buying an automobile

H1: There is a significant association between perceived quality and purchase decision.

As suggested by Groth (1995), perceived value is important factor in purchase or consumption decisions. According to Heskett et al. (1997), customers purchase decision is affected by the value offered by product or service. Customers are interested to know what kind of benefit or values they can obtain from the products; purchase decision is affected by the perceived value (Leung and $\mathrm{Li}$, 1998). Based on the statement by previous researchers, this study would like to know whether perceived value would have positive effect towards customer purchase decision. Thus, the second hypothesis would be:

$\mathrm{H} 2$ : There is a significant association between perceived value and purchase decision.

Many studies attempted to measure risk perception in a broader marketing context (Tzeng et al., 2005; Cox, 1967; Bagheri et al., 2008; Roselius, 1971; Taylor, 1974; Greatorex and Mitchell, 1993; Yavas, 2003; Agrawal and Teas, 2002; Tse, 1999) where the risky or uncertain outcome in a purchase decision is that a product does not perform according to perception. Such research focuses on outcomes that are more disappointing than they are threatening to consumer welfare; more to do with a product underperforming than being unsafe. The consumer may be unhappy but is not necessarily exposed to a hazard (Ruth and Joe, 2001). Based on the statement by previous researchers, this study would like to investigate whether perceived risk would have negative effect towards customer purchase decision. Thus, the third hypothesis would be:

H3: There is a significant association between perceived risk and purchase decision.

Research design: Research design is a master plan specifying the methods and procedures for collecting and analyzing the needed information (Zikmund, 2003). In this study, descriptive research was used due to its usefulness to describe the market phenomenon, such as measuring the purchase decision towards automobile in 
competitive environment and to show that whether the constructs lead to customer purchase decision. It is a type of conclusive research that has as its major objective the description of something-usually market characteristics or functions.

According to Burns and Bush (2003), descriptive analysis is used to define the sample characteristics of the typical respondent and disclosing the general pattern of response. Descriptive research known as statistical research, describes data about the population being studied. It consists of mean, percentage, causal and range. Beside that it also used to describe, explain or summarize the information of the sample.

The purpose of this research is to determine the significant association of the independent variables that can lead customers to purchase an automobile. Descriptive research was used because we have prior knowledge about the problem situation as it is discovered through the past studies. In order to find the relationship among the three variables, this research has been conducted.

Sampling design: Questionnaire survey method was used to collect data for this research study. 200 of questionnaires were distributed in Klang Valley, due to the ease, reliability and simplicity. Questionnaires using 5-point Likert scale with anchor of (1) 'strongly disagree' to (5) 'strongly agree' can reduce variability in the results that may be differences and enhances reliability of the responses. Besides, it also simplifies coding, analysis and interpretation of data.

Target population for this research is the customers at the age between 23-65 years old and above. As our study context is in high-end product category, so those target population are suitable because they has higher disposable income and they need an automobile as transportation. These groups of people are more focus on car performance, value, quality and risk as consideration to measure when they want to purchase an automobile. Klang Valley is the target location to obtain the respondents because of high pedestrian traffic. Besides, many car companies have set up their showroom in Klang Valley (UMW Toyota Motor, 2008).

Convenience sampling is used to obtain a sample of element because it is impossible to estimate or calculate the probability of the selection for each element in the population. Convenience sampling is where the respondents are selected because they happen to be at the right place and at the right time. Researcher just needs to contact the target element in Klang Valley to who are easily located and willing to participate. Convenience sampling can achieve cost efficient and save time. It is because the sampling units tend to be easily accessible and the most important is that the proportion of target population has no significance on the validity of the conclusion.

This survey will be conducted on weekdays and weekends to ensure that the sample is included in peak hours and non peak hours. 200 people will be included in the survey. Roscoe (1979) proposed that the rules of thumb for determining the sample size which more than 30 and less than 500 are appropriate for the most research. A pilot test was conducted before the actual survey took place. 20 sets of questionnaires were distributed out during the pilot test in order to ensure no mistake or error occurred within the questionnaire. It is essential to know the weakness and potential error in the questionnaire before actual survey take place. Some changes also been corrected after distributed the pilot test such as grammar error and spelling mistake.

\section{RESULTS}

Internal reliability test: Reliability test is used to determine the stability and consistency with which the research instrument measures the constructs (Malhotra, 2004). In other words, reliability is concerned with the stability and consistency in measurement. Furthermore, the relationship between individual items in the scale also can be determined significantly. Cronbach's Alpha reliability test is used by averaging the coefficient that result from all possible combinations of split halves. As Malhotra (2004) stated, the coefficient varies from 0-1 AND value of 0.6 or less generally signifies unsatisfactory internal consistency reliability. Alpha coefficients below 0.6 are weak in reliability, 0.6-0.8 are moderate strong and $0.8-1.0$ are very strong in reliability (Malhotra, 2004).

From the reliability test shown in Table 1, 6 items have been included in measuring perceived quality and the alpha coefficient is 0.793 . By using 5 items in perceived value, the alpha coefficient is 0.843 . Furthermore, there are 5 items used to measure perceived risk and the alpha coefficient is 0.747 . For purchase decision, there are 5 items used in the measurement and the alpha coefficient is 0.857 . Overall, the internal reliability coefficients for the entire constructs are moderate strong to very strong as all alpha coefficients are more than 0.7. Thus, the internal reliability test indicates that all of the measures adopted have internal consistency reliability. The internal reliability test of perceived quality, perceived value, perceived risk and purchase decision are above 0.7, which is acceptable as the minimum level of 0.6 for further analysis. Thus, we can conclude that all the items that used to measure the 4 constructs are stable 
Am. J. of Economics and Business Administration 3 (1): 47-57, 2011

Table 1: Reliability test

\begin{tabular}{llll}
\hline Number & Constructs & $\begin{array}{l}\text { Alpha } \\
\text { coefficient }\end{array}$ & $\begin{array}{l}\text { Number } \\
\text { of items }\end{array}$ \\
\hline 1 & Perceived quality & 0.793 & 6 \\
2 & Perceived value & 0.843 & 5 \\
3 & Perceived risk & 0.747 & 5 \\
4 & Purchase decision & 0.857 & 5 \\
\hline
\end{tabular}

Table 2: Pearson's correlation analysis

\begin{tabular}{lllll}
\hline Variables & PQ & PV & PR & PD \\
\hline PQ & 1.000 & & & \\
PV & $0.602^{*}$ & 1.000 & & \\
PR & $0.506^{*}$ & $0.581^{*}$ & 1.000 & \\
PD & $0.642^{*}$ & $0.637^{*}$ & $0.589^{*}$ & 1.000 \\
\hline
\end{tabular}

Notes: *Correlation is significant at the 0.01 level (2-tailed)

and consistent. In conclusion, the relationships among the items are reliable for further analysis.

Pearson's correlation analysis: Correlation analysis is a statistical summarizing the strength of association between two metric variables (Malhotra, 2004) which called Pearson's Correlation Analysis. It indicates the strength and direction of linear association between two random variables (Malhotra, 2004). Pearson's correlation coefficient is used to analysis the relationship between the variables. This analysis is to measure the co variation or association between the variables likes for example consumers purchase decision on automobile and the three elements such as perceived quality, perceived value and perceived risk.

Based on Hair et al. (2003), Pearson correlation coefficient (r) measures "the linear of association between two metric (interval or ration scaled) variables". The coefficient (r) indicates both the magnitude of the linear relationship and the direction of the relationship. The correlation coefficient ranges from +1.0 indicates perfect positive relationship to -1.0 indicates perfect negative relationship and value of 0 indicates no linear relationship. The larger correlation of coefficient, is the stronger the linkage or level of association between two metric variables. This test will be done at $5 \%$ significance level. The null hypothesis (H0) would be rejected if the significance value, $p$, obtained were less than the value of alpha that has been set at 0.05 . In other words, if, p-value $<0.05$, reject $\mathrm{H} 0$; if, p-value $>0.05$, failed to reject $\mathrm{H} 0$.

Results from Table 2 show significant positive correlation between independent variables and dependent variable. According to Hair et al. (2006), multicollinearity occur if the r-value between each pair of independent variable in Pearson's correlation exceed 0.90. Perceived quality with perceived value scores the highest value (0.602) among those independent variables, which is $<0.90$. Thus, there is no multicollinearity problem in this study.
Normality test: In data analysis, it is important to screen through the data for meeting the normality assumptions for all parametric statistical techniques. Hair et al. (2006) identify the two most common tests use to check for normality, that are the Shapiro-Wilk test and a modification of the Kolmogorov-Smirnov test. According to Hair et al. (2006), the p-value must be greater than 0.05 in order to meet the normality assumptions. Testing the normality of standardized residuals using Kolmogorov-Smirnov with Lilliefors significance correction was applied in this study. Based on the results, the p-value (Sig.) for KolmogorovSmirnov test is 0.200 , which is greater than 0.05 (i.e., $n>100)$. Thus, the data of standardized residuals can assume to be normally distributed.

Multiple regression analysis: Since this study intent to examine the relationship between three independent variables, namely perceived quality, perceived value and perceived risk and one dependent variable, namely purchase decision, thus, multiple regression analysis is the most appropriate test to apply. According to Hair et al. (2006), multiple regression analysis is a statistical technique used to test the relationship between more than one independent variables and a single dependent variable, given the condition that both variables must be metric. Therefore, it is applied in this study to examine the metric data of perceived quality, perceived value and perceived risk (three independent variables) and purchase decision (one dependent variable), respectively.

From Table 3, all the variables has tolerance values above 0.10 (range from 0.534-0.624) and Variance Inflation Factors (VIF) values below 10.0 (range from 1.602-1.872). Therefore, multicollinearity problem does not exist. Based on Cohen's rules for effects sizes, the coefficient of determination $\left(\mathrm{R}^{2}\right)$ was 0.550 , which means that $55 \%$ of purchase decision can be explained by the three independent variables. Thus, the effect size for this study is large. The proposed model was adequate as the F-ratio $=79.703(\mathrm{p}$-value $=0.000)$ was significant at $1 \%$ level $(\mathrm{p}<0.01)$.

\section{Hypothesis testing:}

H1: There is a significant association between perceived quality and purchase decision.

According to Table 3, significant value for perceived quality is $0.000(\beta=0.339)$, which indicates that perceived quality towards purchase decision is more than $99.99 \%$ (p-value<0.01). Therefore, $\mathrm{H} 1$ is supported and this indicates that perceived quality has 
Am. J. of Economics and Business Administration 3 (1): 47-57, 2011

Table 3: Results of multiple regression analysis

\begin{tabular}{|c|c|c|c|c|c|c|c|}
\hline \multirow[b]{2}{*}{ Model } & \multicolumn{2}{|c|}{ Unstandardized coefficients } & \multirow[b]{2}{*}{$\begin{array}{l}\text { Standardized } \\
\text { coefficients } \beta\end{array}$} & \multirow[b]{2}{*}{$\mathrm{t}$} & \multirow[b]{2}{*}{ Sig. } & \multicolumn{2}{|c|}{ Collinearity statistics } \\
\hline & 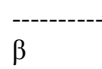 & SE & & & & Tolerance & VIF \\
\hline 1 (Constant) & 0.954 & 1.304 & & 0.731 & 0.465 & & \\
\hline $\mathrm{PQ}$ & 0.339 & 0.061 & 0.344 & 5.569 & $0.000^{* *}$ & 0.601 & 1.665 \\
\hline PV & 0.269 & 0.062 & 0.285 & 4.350 & $0.000^{* *}$ & 0.534 & 1.872 \\
\hline PR & 0.296 & 0.072 & 0.249 & 4.101 & $0.000^{* *}$ & 0.624 & 1.602 \\
\hline $\mathrm{R}^{2}$ & 0.550 & & & & & & \\
\hline Adjusted $\mathrm{R}^{2}$ & 0.543 & & & & & & \\
\hline Sig. F & 0.000 & & & & & & \\
\hline F-value & 79.703 & & & & & & \\
\hline
\end{tabular}

direct association with purchase decision when customers want to purchase a car. This mean if customers' perceived quality on automobile is higher, purchase decision will be higher and will have high intention to purchase.

$\mathrm{H} 2$ : There is a significant association between perceived value and purchase decision.

According to Table 3, significant value for perceived value is $0.000(\beta=0.269)$, which indicates that perceived value towards purchase decision is more than $99.99 \%$ (p-value<0.01). Therefore, $\mathrm{H} 2$ is supported, which indicates that perceived value has direct association with purchase decision when customers want to purchase a car. This mean that, if customers perceived value on automobile is higher, purchase decision will be higher and they will have high intention to buy.

H3: There is a significant association between perceived risk and purchase decision.

According to Table 3, significant value for perceived risk is $0.000(\beta=0.296)$, which indicates that perceived risk towards purchase decision is more than 99.99\% (p-value<0.01). Therefore, H3 is supported, which indicates that perceived risk have association with purchase decision when customers want to purchase a car.

\section{DISCUSSION}

Managerial implications: When customers want to purchase a car, they look for reliability and durability of the cars. Normally customers think those high quality cars are those car which adopt advance technology and have high performance which lead to longer lifetime of the cars. Besides, they think that high quality car will provide them comfortable and help them to save unnecessary repairing cost. Customers refuse to purchase low quality cars because probability of defect for low quality cars are higher and this will end up with high cost in repair and maintenance.

Therefore, it is recommended for automobile companies that they should dedicate sufficient budget and resource to improve the quality of their cars. With regard to technology, automobile companies should invest more advance technology for engine such as Hybrid engine that save up fuel consumption. Moreover, they should also improve their quality system on operation, such as practicing Lean Manufacturing.

Along with flourish of technology and citizens are more educated than before, most of the customers have more product knowledge and more sources of information. Hence, they have more rigorous and harsh requirement to consider before they make a decision in purchasing car. Therefore, in making car purchasing decision, most of the customers will consider what value the company can offer to them in terms of money, personality, status and lifestyle. Customers will think of the value that can provided by a particular car in term of status, personality and lifestyle. They want to have higher status, unique personality and better lifestyle by driving that car. Thus, probability to purchase that car will be higher if the company able to provide such value.

Due to this, automobile companies should further strengthen the value to their cars. In advertisement they should emphasize the value that the cars can give to their user. They need to educate their customers that what kind of status, personality and lifestyle will be if they drive those cars. Besides that, automobile companies should have value added services for their customers. For example, when customers go to their showroom, the sales representative will greet their customers, serve them with drinks and provide customer with detail information about cars. Other than that, special body kit and tinted window also provided to the cars user. Besides, special package such as cash rebate and free milestone services are given to 
customers according to the car model. By doing so, customers will felt that the value provided by the companies is excellent.

Finally, customers will consider some risk when they want to purchase cars because car is one of the expensive asset and most of the consumer perceive that car should be long lasting. Therefore, they face uncertainty if they purchase the unsuitable car that result in poor performance, embarrassment, poor self image and unsafely, which cause them lost in financial risk, physical risk, social risk and performance risk. So, customers will tend to purchase cars that value for money.

Thus, automobile companies should use advertising to convince their customers that the risks (in term of performance and safety) for purchasing their cars are much lower than others. They can emphasize on raw materials that they are use to assemble the cars such as solid materials and high technology. Moreover, they can stress on Anti-Lock Brake System (ABS) and airbag in order to reduce perceived risk of customers. Besides that, automobile companies should position them as a high status brand to convince people that they will not felt embarrass by driving their cars. Moreover, they should extend the warranty period of their cars in order to reduce the risk bear by customers.

Limitations of the study: Firstly, the data collection methods being used for this research may not represent the true population of the targeted respondent. It shows that most of the respondents were come from the Chinese ethic group. Therefore, the research report might not produce comprehensive results as there were few Malays and Indians respondents that aid in the research process.

Besides, most of the respondents came from the age group of 23-30 years old which mostly are Generation Y. Therefore, the research result might not comprehensive enough as there are only few numbers of respondents who are Generation $X$ and Baby Boomers. Moreover, the result may be bias due to the different purchase behaviors among these 3 groups.

In addition, we had faced difficulties in obtaining the relevant information from existing resources such as the internet search engine, reference book and so on. Due to the collection of secondary data was collected via Internet and reference books; information regarding customer purchase decision towards cars is limited. Although there are many articles and research posted online, there was lack of related information that can be used as a reference for our research title. More than that, we had found many other related articles but a subscription need to be made in order to access those articles.
We also faced languages barriers when conducting the data collection process. This is because majority of the respondents are Chinese who are from Chinese educated background and they have some difficulties in understanding the question being asked in the questionnaire as well as poor command of English Language. In turn this affected the accuracy and reliability of the result. Besides, the questionnaires were distributed among the respondents from Klang Valley, thus it cannot be generalize for the whole population in Malaysia and the result obtained might not be reliable as it only includes the opinion and feedback from the respondents in this selected area.

Besides that, most of the respondents in Klang Valley are not willing to provide us information needed. Thus, we faced difficulties in finding respondents who are willing to fill the questionnaire for us. As a result, we spend more than a week and travel many places in Klang Valley in order to obtained 200 copies questionnaires feedback. Finally, due to the time constraint, financial constraint and limited facilities in assisting us to conduct our research project, therefore, this indirectly will influence the comprehension of our research project.

Recommendations for future research: In our research, the data are collected from Klang Valley. We should open the survey to more locations in future so reduce the bias of result. In future, the research can be expanded to other states in Malaysia such as Johor, Pulau Pinang and Perak. We also should balance the races among Malay, Chinese and Indian as our respondents. Thus the questionnaires can be written in other languages such as Mandarin and Malay.

Besides, the number of respondent can be increased to cover all state in Malaysia in order to be more representative. This can further increase the representative of our data. The increase of respondents can be done by sending the questionnaires through internet to target respondent. This is because we can control the demographic of respondent such as age and reduce the non-respondent to answer our questionnaires.

Lastly, in our research we should include other factor that will influence customers purchase decision towards automobile such as price, service quality and so forth. This can keep our finding more complete due to the newly developed model that is better suit to current environmental changes.

\section{CONCLUSION}

From this research, majority of customers will consider quality when they intend to purchase cars. 
This result is further supported by Dae and Joon (2009); Tsiotsou (2006); Richardson et al. (1996); Hoch and Banerji (1993), which indicate that perceived quality have positive association with purchase decision. The result is same with others because we adopted the same positive question as others to measure on perceived quality in our questionnaire. In pace with the economic become prosperity, the citizens have more disposable income. Thus, they seek for another level on automobile because they no longer perceive that car is mainly for transport purpose but it is more than that. They are looking for high quality and low risk car together with the after sales services provided.

Similar with Ching and Hsi (2007); Mahmud et al. (2008); Eggert and Ulaga (2002), which indicate that perceived value have positive association with purchase decision, our results also indicate that value is another factor customers will concern about when they want to purchase cars. This is because same positive questions have been used in our questionnaire to measure perceived value in our questionnaire as others researchers done. Whenever customers make purchase decision on cars, they will think that whether the cars are worth to buy or not.

For perceived risk, although it shows the relationship between perceived risk and purchase decision, however, the result is contrast with Yavas (2003); Agarwal and Teas (2002) and Ruth and Joe (2001), which show the negative association between both variables. The result is contrast due to the quality of our respondents, the use of positive question about perceived risk are set in questionnaire compare to all the researchers, where negative question are use to ask about perceived risk.

\section{ACKNOWLEDGEMENT}

We hereby appreciate Tan Joo Beng, Tan Kai Seng and Tay Wee Kian Alvin for the help in collecting data and analyzing the data. We also are grateful to the survey respondents in Klang Valley, Malaysia, who provided valuable information and data for this study. Part of this study was presented in Knowledge Management International Conference (KMICe) 2010 (index by Thomson ISI) at Primula Beach Resort, Kuala Terengganu, Malaysia on 25-27 May 2010.

\section{REFERENCES}

Aaker, D.A., 1991. Managing Brand Equity: Capitalizing on Value of a Brand Name. The Free Press, New York, ISBN: 0-02-900101-3, pp: 299.
Agarwal, S. and R.K. Teas, 2002. Cross-national applicability of a perceived quality model. J. Product Brand Manage., 11: 213-236. DOI: 10.1108/10610420210435425

Ahmed, Z.U., J.P. Johnson, P.L. Chew and W.F. Tan et al., 2002. Country-of-origin and brand effects on consumers' evaluations of cruise lines. Int. Market. Rev., 19: 279-302. DOI: 10.1108/02651330210430703

Anckar, B. and D. D'Incau, 2002. Value creation in mobile commerce: Findings from a consumer survey. J. Inform. Technol. Theory Appli., 4: 4364. ISSN: 15324516

Armstrong, G. and P. Kotler, 2003. Marketing: An Introduction. 6th Edn., Pearson Prentice Hall, New Jersey, ISBN: 0-13-035133-4, pp: 714.

Bagheri, A., H.S. Fami, A. Rezvanfar, A. Asadi and S. Yazdani, 2008. Perceptions of paddy farmers towards sustainable agricultural technologies: case of haraz catchments area in mazandaran province of Iran. Am. J. Applied Sci.., 5: 1384-1391. ISSN: 15469239

Batra, R. and I. Sinha, 2000. Consumer-level factors moderating the success of private labels brands. J. Retail., 76: 175-191. DOI: 10.1016/S0022435900000270

Bettman, J.R., 1979. Memory factors in consumer choice: A review. J. Market., 43: 37-53. ISSN: 00222429

Blackwell, R.D., P.W. Miniard and J.F. Engel, 2006. Consumer Behavior. 10th Edn., Southern Western Publisher, Thomson, USA., ISBN: 8-13-150184-1, pp: 816.

Burns, A.C. and R.F. Bush, 2003. Marketing Research: Online Research Application. 4th Edn., Prentice Hall, New Jersey, ISBN: 0-13-035135-0, pp: 672.

Ching, W.C. and P.L. Hsi, 2007. Factors influencing online music purchase intention in Taiwan: An empirical study based on the value-intention framework. Inter. Res., 17: 139-155. DOI: 10.1108/10662240710737004

Cox, D.F., 1967. Risk Handling in Consumer Behavior: An Intensive Study of two Cases. Risk Taking and Information Handling in Consumer Behavior. Harvard University Press, Boston, MA., ISBN: 9780875840635, pp: 82-108.

Cronin, J.R., J.J., Brady, M.K. Hult and G.T.M., 2000. Assessing the effects of quality, value and customer satisfaction on consumer behavioral intentions in service environments. J. Retail., 76: 193-218. DOI: 10.1016/S0022435900000282 
Dae, H.K. and H.K. Joon, 2009. Symbolic purchase in sport: The roles of self-image congruence and perceived quality. Manage. Decis., 47: 85-99. DOI: 10.1108/00251740910929713

Davis, Aquilano and Chase, 2003. Fundamentals of Operations Management. 4th Edn., McGrawHill/Irwin, ISBN: 0-07-297541-5, pp: 1.

Dowling, R. and R. Staelin, 1994. A model of perceived risk and intended risk handling activity. $\mathrm{J}$. Consumer Res., 21: 110-134. DOI: 10.1086/209386

Dunn, M.G., P.E. Murphy and G.U. Skelly, 1986. Research note: The influence of perceived risk on brand preference for supermarket products. J. Retail., 62: 204-217. ISSN: 00224359

Durovnik, C., 2006. From "Experience" Goods to "Search" http://icommons.org/2006/08/22/from$\%$ E2\%80\%98experience\%E2\%80\%99-goods-to$\%$ E2\%80\%98search\%E2\%80\%99-goods/

Eggert, A. and W. Ulaga, 2002. Customer perceived value: A substitute for satisfaction in business markets. J. Bus. Ind. Market., 17: 107-118. DOI: 10.1108/08858620210419754

Gan, C., V. Limsombunchai, M. Clemes and A. Weng, 2005. Consumer choice prediction: Artificial neural networks versus logistic models. J. Soc. Sci.., 1: 211-219. ISSN: 15493652

Greatorex, M. and V.W. Mitchell, 1993. Developing the perceived risk concept: Emerging issues in marketing. Proceedings of the Marketing Education Group Conference, pp: 405-415.

Groth, J.C., 1995. Exclusive value and the pricing of services. Manage. Decis., 33: 22-29. DOI: 10.1108/00251749510093905

Hair, J.F., B. Babin, A.H. Money and P. Samouel, 2003. Essentials of Business Research Methods. John Wiley and Sons, New York, ISBN: 0-47127136-5, pp: 464.

Hair, J.F., JrW.C. Black, B.J. Babin, R.E. Anderson and R.L. Tatham, 2006. Multivariate Data Analysis. 6th Edn. Pearson Education, Upper Saddle River, NJ., ISBN: 0-13-032929-0, pp: 928.

Havlena, W.J. and W.S. De Sarbo, 1991. On the measurement of perceived consumer risk. Decis. Sci., 22: 927-939. DOI: 10.1111/j.15405915.1991.tb00372.x

Heskett, J.L., W.E. Jr Sasser and L.A. Schlesinger, 1997. The Service Profit Chain. How Leading Companies Link Profit and Growth to Loyalty, Satisfaction, and Value, The Free Press, New York, ISBN: 0-68-483256-9, pp: 320.
Hoch, S.J. and S. Banerji, 1993. When do private labels succeed. Sloan Manage. Rev., 34: 57-67. PMID: 66610

Jin, B. and G.S. Yong, 2005. Integrating effect of consumer perception factors in predicting private brand purchase in a Korean discount store context. J. Consumer Market., 22: 62-71. DOI: 10.1108/07363760510589226

Kotler, P., G. Armstrong, H.A. Swee, M.L. Siew and T.T. Chin et al., 2005. Principles of Marketing: An Asian Perspective. 11th Edn. Prentice Hall, Pearson Education South Asia, ISBN: 0-13123439-0, pp: 608.

Leung, K. and W.K. Li, 1998. The impact of customer service and product value on customer loyalty and purchase behavior. J. Applied Soc. Psychol., 28: 1731-1741. DOI: 10.1111/j.15591816.1998.tb01343.x

Mahmud, A.S., K. Uma and K. Vinod, 2008. Role of different Electronic-Commerce (EC) quality factors on purchase decision: A developing country perspective. J. Elect. Commerce Res., 9: 92-113. ISSN: 15266133

Malhotra, N.K., 2004. Marketing Research: An Applied Orientation. 4th Edn. Pearson Education, Inc., New Jersey, ISBN: 0-13-033716-1, pp: 864.

Mark, 2009. ASEAN automotive market review. http://www.allbusiness.com/legal/internationaltrade-law-treaties-agreements-free/133803291.html

Mitchell, V.W., 1992. Understanding consumers' behavior: Can perceived risk theory help. Manage. Decis., 30: 26-31. DOI: $10.1108 / 00251749210013050$

Mokhtar, A.S., K.A. Abbas, S.M. Sapuan and M.M.H. Ahmad, 2005. Consumer's acceptability estimation of cold preserved Malaysian freshwater patin. Am. J. Applied Sci., 2: 985-988. ISSN: 15469239

NQRC, 1995. American Consumer Satisfaction Index Methodology_ Report. http://en.wikipedia.org/wiki/American_Customer_ Satisfaction_Index

Palaniappan, R., 2009. 23rd AFTA Council Meeting. http://www.miti.gov.my/cms/content.jsp?id=com.t ms.cms.article.Article_260a493c-c0a81573$8 \mathrm{c} 608 \mathrm{c} 60-2854 \mathrm{c} 0 \mathrm{bb}$

Peter, J.P. and J. Olson, 2004. Consumer Behavior and Marketing Strategy. 7th Edn. McGraw-Hill/Irwin, ISBN 0-07-286487-7, pp: 608.

Peter, J.P. and M.J. Ryan, 1976. An investigation of perceived risk at the brand level. J. Market. Res., 13: 184-188. ISSN: 00222437 
Richardson, P.S., A.K. Jain and A. Dick, 1996. Household store brand proneness: A framework. J. Retail., $\quad 72$ : 159-185. DOI: $10.1016 / \mathrm{S} 0022435996900123$

Roscoe, J.T., 1979. Fundamental Research Statistics for the Behavioral Sciences. 2nd Edn. Holt Rinehart and Winston, New York, ISBN: 0-03-091934-7, pp: 483.

Roselius, T., 1971. Consumer rankings of risk reduction methods. J. Market., 35: 56-61. ISSN: 00222429

Rust, R.T. and R.L. Oliver, 1994. Service Quality: Insights and Managerial Implications from the Frontier. Service Quality: New Directions in Theory and Practice. 1st Edn. Sage, Thousand Oaks, CA., ISBN: 0-80-394920-0, pp: 294.

Ruth, MW. and M. Joe, 2001. Food safety risk: Consumer perception and purchase behaviour. British Food J., 103: 170-187. DOI: 10.1108/00070700110386728

Schiffman, L.G., 1972. Perceived risk in new product trial by elder consumers. J. Market. Res., 9: 106-108. ISSN: 00222437

Stonewall, D.W., 1992. How to define and measure value. Executive Excell., 9: 16-17. ISSN: 87562308

Sweeney, J.C. and G.N. Soutar, 2001. Consumer perceived value: The development of a multiple item scale. J. Retail., 77: 203-220. DOI: $10.1016 / \mathrm{S} 0022435901000410$

Taylor, J.W., 1974. The role of risk in consumer behavior, J. Market., 38: 54-60. ISSN: 00222429

Tse, A.C.B., 1999. Factors affecting consumer perceptions of product safety. Eur. J. Market., 33: 911-925. DOI: 10.1108/03090569910285841
Tsiotsou, R., 2006. The role of perceived product quality and overall satisfaction on purchase intentions. Int. J. Consumer Stud., 30: 207-217. DOI: $10.1111 / \mathrm{j} .1470-6431.2005 .00477 . \mathrm{x}$

Tzeng, S.C., J.P. Yeh and W.P. Ma, 2005. Industrialacademic co-operation of technical university and automobile industry in Taiwan. Am. J. Applied Sci., 2: 367-371. ISSN: 15469239

UMW Toyota Motor, 2008. Sales Locator. http://www.toyota.com.my/customerservicesaleslocator.aspx

Woodruff, R.B., 1997. Customer value: The next source for competitive advantage. J. Acad. Market. Sci., 25: 139-153. DOI: 10.1007/BF02894350

Yavas, U., 2003. A multi-attribute approach to understanding shopper segments. Int. J. Retail Distribut. Manage., 31: 541-548. DOI: 10.1108/09590550310503276

Zeithaml, V.A. and M.J. Bitner, 2003. Services Marketing: Integrating Customer Focus Across the Firm. 3rd Edn. McGraw-Hill, New York, ISBN: 007-119914-4, pp: 624.

Zeithaml, V.A., 1988a. Consumer Perceptions of price, quality and value: A means-end model and synthesis of evidence. J. Market., 52: 2-22. ISSN: 00222429

Zeithaml, V.A., 1988b. Communication and control processes in the delivery of service quality. $\mathrm{J}$. Market., 52: 35-48. ISSN: 00222429

Zikmund, W.G., 2003. Business Research Methods. 7th Edn., Thompson-South Western, Ohio, ISBN: 0-32-418239-2, pp: 736. 